American Journal of Environmental Sciences 7 (6): 547-553, 2011

ISSN 1553-345X

(C) 2011 Science Publications

\title{
Environmental Radioactive Impact Associated to Uranium Production
}

\author{
Fernando P. Carvalho \\ Nuclear and Technological Institute \\ Department of Radiological Protection and Nuclear Safety, \\ E.N. 10, 2686-953 Sacavem, Portugal
}

\begin{abstract}
Problem statement: One century of uranium mining in Europe and North-America created a legacy of ore mining and milling sites needing rehabilitation for environmental and human safety. In the last decades developments of uranium mining displaced the core of this activity to Australia, Canada and African countries. In the coming years, uranium mining is expected to grow further, in those countries and elsewhere, due to the possible increase of nuclear power production and thus the amount of radioactive and toxic tailing materials will grow. Approach: International radiation protection guidelines and legislation have known recent developments and set the radiation dose limit applied to members of the public at $1 \mathrm{mSv}^{-1}$. Taking into account past and present uranium waste management and environmental remediation measures adopted already in some countries, we assessed the implications of enforcing this new dose limit in uranium milling and mining areas. Results: The radioactive impact of uranium mining and milling was illustrated through case studies. Environmental radioactivity monitoring and surveillance carried out in areas impacted by uranium mining and milling industry showed generally that dose limit for members of the public was exceeded. The compliance with this dose limit is nowadays the main goal for environmental remediation programs of legacy sites implemented in European Union countries. Taking into account the new radiation protection regulations, a change is required in mining practices from traditionally reactionary (problem solving) to proactive (integrated management) and life-cycle approach. Conclusion: A new paradigm in uranium mining should be implemented worldwide to ensure reduced environmental radioactivity impact current and future reduced radiation risk exposure of population.
\end{abstract}

Key words: Uranium mines, radiation exposure, environmental remediation, environmental radioactivity, uranium mining, uranium production, European Union, radioactive impact, radiation protection, milling tailings

\section{INTRODUCTION}

The nuclear fuel cycle is based on uranium and it includes a number of steps, from the extraction of geological resources to the disposal of spent nuclear fuel materials. These steps include uranium mining (ore finding and extraction), ore milling (physical and chemical uranium extraction from the ore), conversion (chemical modification into gaseous $\mathrm{UF}_{6}$ ), enrichment (increasing the ${ }^{235} \mathrm{U}$ mass abundance in the ore from $0.71 \%$ up to $3.5 \%-5 \%$ ), fuel fabrication (producing $\mathrm{UO}_{2}$ pellets for nuclear fuel rods), power generation (through fission reaction in the nuclear reactor core) and storage of spent fuel (either for reprocessing and plutonium and uranium re-use, or for deep geological waste disposal) (Eisenbud and Gesell, 1997; Hala and Navratil, 2003).
All these steps of the nuclear fuel cycle generate radioactive wastes, but the largest waste volume, although not the most radioactive, consists of uranium mining and milling tailings. As an example of the quantities involved, a typical Light Water Reactor (LWR) producing 900 MegaWatts of electrical power (MWe) consumes as fuel 20 tonnes of metallic uranium (about 22.7 tonnes $\mathrm{UO}_{2}$ ) per year. This amount of uranium fuel is enriched to about $4 \%{ }^{235} \mathrm{U}$, obtained from 160 tonnes of $U$ in the chemical form of $U_{6}$, which in turn requires the mining of 17,000 tonnes of uranium ore of $1 \% \mathrm{U}$ grade (Eisenbud and Gesell, 1997; Hala and Navratil, 2003). During ore processing for uranium production, most ore materials end up in the mill tailings including all radioactive elements present therein, in particular those of the uranium radioactive decay series (IAEA, 2005b; Carvalho et al., 2007a). 
Worldwide there are about 437 nuclear power plants in operation, with a producing capacity of $370 \mathrm{GWe}$ and another 55 are currently under construction (IAEA, 2006). In $2003,36,000$ tonnes of metallic uranium were produced, representing nearly half of the annual uranium fuel requirement for electric power production $(66,000$ tonnes). Remaining fuel was obtained from spent nuclear fuel reprocessing, weapons grade (military) uranium and civilian uranium stockpiles made by countries in the previous decades CEA 2008. Due to decreasing uranium amounts in stockpiles and to increasing interest in nuclear energy, market price of uranium peaked in 2007. As an effect, it seems likely that uranium production will increase in coming years, especially because of increasing demand for cleaner energy in conjunction with the rapid decline in oil production (Malyshkina and Niemeier, 2010). Since the demonstrated recoverable uranium resources are estimated at about 4.5 million tones of metallic uranium, these will allow for a noticeable expansion of the uranium mining industry. This increase will lead to a concomitant substantial increase in the world volume of uranium mining and milling tailings (IAEA/OECD, 2010).

Current estimates of the uranium tailings volume in the world is 938 million cubic meters resulting from the operation of more than 4,400 uranium mines (IAEA, 2005a). These data compiled by the International Atomic Energy Agency (IAEA), showed that uranium mining and milling tailings are widespread, from Canada to Australia and from Portugal to Kazakhstan. The largest amounts of uranium tailings were disposed of in the European Union countries especially in Germany (34\%), Kazakhstan (23\%), USA (13\%) and Canada (3\%). Milling tailings are found in significant amounts in small countries as well. Most uranium producers operating small mines in Western Europe (e.g., in France, Spain, Portugal, Hungary, Slovenia), ceased activities during the 1980's and 1990's and the tailings became a legacy from past radium and uranium production. With the recent discovery of large uranium ore deposits in Australia, Canada, Kazakhstan, Malawi and in several other countries, mining and milling tailings will increase further. These tailings will contain above background radioactivity and are a matter of environmental health concern (IAEA, 2005a; Carvalho et al., 2007b).

The international basic safety standards to protect human health and the environment against the harmful effects of ionizing radiation were reviewed by the International Commission on Radiological Protection (ICRP) and new and more stringent dose limits were set at $1 \mathrm{mSv} \mathrm{y}^{-1}$ and $100 \mathrm{mSv}$ over $5 \mathrm{y}$, for members of the public and workers respectively (ICRP, 1991).
Following ICRP recommendations, also approved by the IAEA and OECD/NEA amongst other international organizations, in the last decade many countries enforced new radiological protection regulations such as, for example, the European Union (EU) following the publication of EU Directive 96/29 Euratom. Combined with other regulations on environmental protection, those radiation safety regulations lead to the remediation of old uranium mine and milling sites. This was achieved already in most EU countries, North America and Australia (OECD/NEA, 2002). The costs of decommissioning and remediation projects in 14 uranium producing countries were estimated at USD 12.9 billion WISE 2002. These remediation projects related mostly to old and abandoned mine and milling sites (legacy sites) and generally were very costly and paid from public funds because mining companies had already walked away or were even extinct.

Suitable environmental remediation of uranium mining and milling sites was not achieved everywhere and certainly it is not ensured yet in many legacy sites, such as those in the Republics of Central Asia with potential for future mining activities that could re-start soon. Likewise, in African countries suitable uranium mining and milling waste management procedures should be implemented. As uranium production has a lasting environmental impact and a potential impact on human health, the proper management of uranium mining operations in developing countries is increasingly required. To achieve this goal a better assimilation of lessons from past uranium mining activities could help.

This study summarizes the main processes and reviews the main radiological hazards associated with the first steps of uranium production industry.

Uranium production: Uranium is currently mined in eighteen countries, seven of which account for $90 \%$ of the world production (Australia, Canada, Kazakhstan, Namibia, Niger, Russian Federation and Uzbekistan) (Euratom Supply Agency, 2009). Worldwide, the uranium ore is extracted by three main procedures: underground mining (27\%), open pit extraction (33\%) and others $(40 \%$, including the uranium in situ leaching procedure and uranium production as a by-product of other mines) WISE 2002 (ESA, 2009). The procedure used depends on economic considerations and geology of the site. All procedures originate some type of waste.

The open pit extraction and underground works give rise to tailings with overburden (overlaying soil and rock usually with low uranium content), barren rock (rock without uranium) and low grade ores (uranium ore with uneconomic uranium grade), usually 
transported and deposited on the surface nearby. In situ leaching consists in the dissolution of uranium ore with aerated water and sulphuric acid and this procedure leaves no mill tailings, although it may originate groundwater contamination. The piles of barren rock (also called «inert materials») usually do not contain above background radioactivity levels and are of no radiological concern. Stockpiles of low grade uranium ores, that may or may not be processed for uranium extraction, can be of some radiological concern in areas with open access.

At the mining step, the main radiological hazards are exposure to uranium ore dust and radon gas in the mine, during transportation and in the storage facilities. The implementation of hygiene and safety measures, including a radiation protection programme at workplaces, is needed and when regulations were enforced it is mandatory. Failure to implement such a radiation protection programme may lead to occupational radiation exposures largely exceeding the radiation dose limit for workers, i.e., $100 \mathrm{mSv}$ over 5 years (ICRP, 1991).

Uranium mill tailings: Uranium ore transported from the mine to the surface is grinded and processed with acid in the milling facilities. The by-product of this acid extraction (or carbonate extraction in the case of carbonated ores) is a sand-like residue, usually pumped as slurry into self-contained surface impoundments (Fig. 1). These mill tailings contain most radioactivity initially present in the ore, due to the uranium decay products (Fig. 2), as well as most of the associated stable metals such as arsenic, tin and vanadium (Merkel and Hasche-Berger, 2006; 2008). In contrast to the mining tailings of barren rock that do not contain elevated radionuclide concentrations, salts deposited from in situ leaching operations and milling tailings from ore processing usually contain high radionuclide concentrations and pose environmental and radiation protection problems. Milling tailings may stay for long time (decades) uncovered and, in general, either covered or uncovered, they will remain significantly radioactive for very long time (several thousand years).tailings materials may contain high concentrations of thorium, especially of those isotopes belonging to the uranium series, such as ${ }^{234} \mathrm{Th}$ and ${ }^{230} \mathrm{Th}$, as well as ${ }^{226} \mathrm{Ra}, 210 \mathrm{~Pb}$ and ${ }^{210} \mathrm{Po}$ (Fig. 2). Most of these radionuclides, initially present in the uranium ore, are alienated from uranium and end up in the mill tailings.

The behavior of mill tailings depends on the remains of chemicals used for uranium extraction and on the rock composition. The most common uranium extractant used is sulphuric acid and acid remains are transferred in the waste water slurry with the rejected materials to the milling tailings. Furthermore, in these tailings often there is in situ production of $\mathrm{H}_{2} \mathrm{SO}_{4}$ from oxidation of pyrite according to the reaction:

$$
\mathrm{FeS}_{2}+7 / 2 \mathrm{O}_{2}+\mathrm{H}_{2} \mathrm{O} \rightarrow \mathrm{Fe}_{2}^{+}+2 \mathrm{SO}_{4}^{2-}+2 \mathrm{H}^{+}
$$

Sulfuric acid lowers the $\mathrm{pH}$ and may operate further uranium leaching from the tailing materials, as in the industrial ore leaching method, according to the reaction:

$$
\mathrm{UO}_{2}+{ }_{3 \mathrm{H} 2 \mathrm{SO} 4}+1 / 2 \mathrm{O}_{2} \rightarrow\left[\mathrm{UO}_{2}\left(\mathrm{SO}_{4}\right)_{3}\right]^{4-}+\mathrm{H}_{2} \mathrm{O}+4 \mathrm{H}^{+}
$$

In the tailings also the ferrous ion may oxidize to ferric ion that, in turn, may react oxidizing $\mathrm{UO}_{2}$ into $\mathrm{UO}_{2}{ }^{2+}$ (Akcil and Koldas, 2006; Borch et al., 2010). In an oxidizing environment the ferric ion may dissolve uranium, as well as other radionuclides and stable metals.

Indeed, in spite of the extraction carried out for uranium production, the uranium is still present in small amounts in the milling tailings and it is represented by three naturally occurring isotopes $\left({ }^{238} \mathrm{U},{ }^{235} \mathrm{U},{ }^{234} \mathrm{U}\right)$. Under oxidizing conditions, $\mathrm{U}^{6+}$ is present as uranyl ion $\mathrm{UO}^{2+}$, easily soluble in water and even more soluble as uranyl carbonate complexes under neutral or alkaline $\mathrm{pH}$.

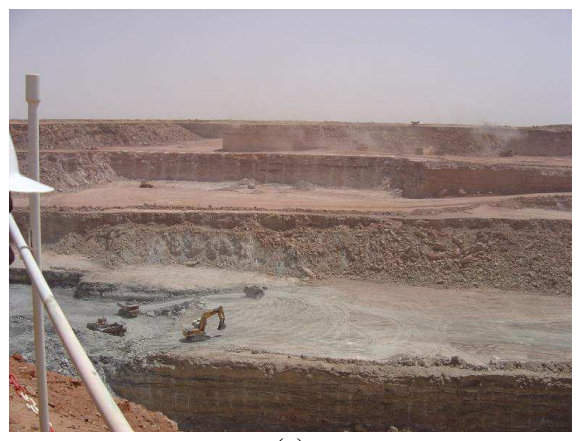

(a)

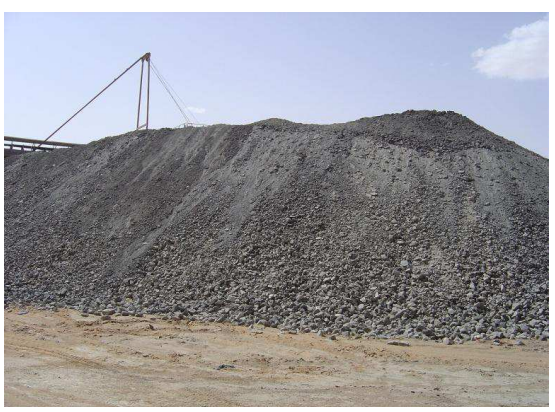

(b)

Fig. 1: Uranium mine in Africa (a) Open pit uranium ore extraction; (b) Uranium milling tailings 
Am. J. Environ. Sci., 7 (6): 547-553, 2011

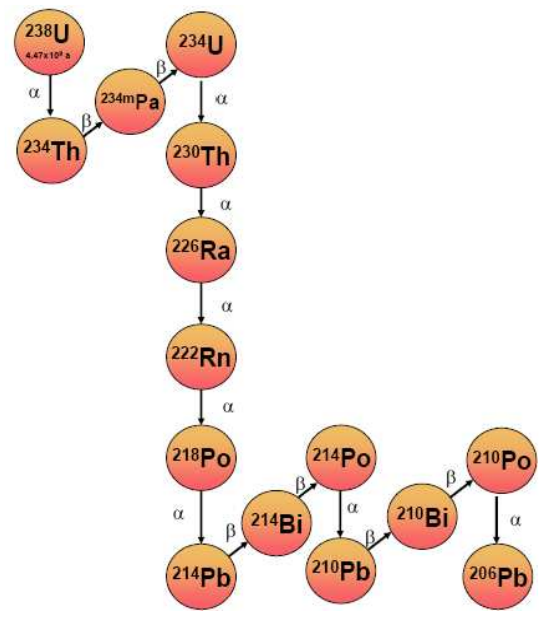

Fig. 2: The uranium radioactive decay series. All ${ }^{238} \mathrm{U}$ daughters are radioactive and the series ends up in the stable isotope ${ }^{206} \mathrm{~Pb}$. In the uranium ore, all these radionuclides generally are in secular radioactive equilibrium

Under reducing conditions, $\mathrm{U}^{4+}$ precipitates as a highly insoluble $\mathrm{UO}_{2}$ form. In the porous media of mill tailings there are reducing and oxidizing micro-environments leading to either precipitation or dissolution of uranium. As a result, leakage from mill tailings usually is fed with percolation water with low $\mathrm{pH}$ and high uranium concentrations. If tailings remain uncovered and exposed to rain water infiltration, they may generate for a long time such acid and radioactive leakage due to continuous formation of $\mathrm{H}_{2} \mathrm{SO}_{4}$ and uranyl ion dissolution.

Other radionuclide concentrations in mill tailings depend upon the initial ore grade, the industrial chemical procedures used and uranium extraction efficiency. Table 1 shows examples of concentrations in mill tailings reported for several mines. The major radiological hazards are represented by the uranium series radionuclides, in particular ${ }^{226} \mathrm{Ra},{ }^{222} \mathrm{Rn},{ }^{210} \mathrm{~Pb}$ and ${ }^{210} \mathrm{Po}$, clearly much higher in those materials than naturally occurring activity concentrations in the soils of the region. Similar results were reported for other countries (OECD/NEA, 2002; IAEA, 2005b).

Radium $\left({ }^{226} \mathrm{Ra}, \mathrm{T}_{1 / 2}=1602 \mathrm{y}\right)$ in the uranium ore is mostly transferred to the tailings, adsorbed onto or coprecipitated with $\mathrm{Fe}-\mathrm{Mn}$ oxyhydroxides. Ra-226 concentrations in mill tailings in Portugal attained 50, $000 \mathrm{~Bq} \mathrm{~kg}{ }^{-1}$ and together with its progeny ${ }^{214} \mathrm{~Pb}$ and ${ }^{214} \mathrm{Bi}$, it originates strong gamma radiation. The total ambient gamma dose measured $1 \mathrm{~m}$ above ground on top of one mill tailings reached $32 \mathrm{mSv} \mathrm{y}^{-1}$, i. e., about 16 times above the background ambient radiation dose in the region (Carvalho et al., 2007a). Under certain conditions radium can be dissolved from the waste tailings by sulfate reducing bacteria and released in tailings leachates (Martin et al., 2003). Furthermore, ${ }^{226} \mathrm{Ra}$ containing leachates may seep into groundwater and contaminate aquifers (IAEA, 2005b; Borch et al., 2010). Radium in solid waste and leachates from milling tailings may also cause radioactive contamination to agriculture soils and rivers nearby. Even deactivated mines and old mill tailings may be a source of radioactive effluents into streams, as found in several old mine areas. The use of contaminated waters in crop irrigation may transfer radionuclides, especially ${ }^{226} \mathrm{Ra}$, to plants, cattle and human consumers (IAEA, 2005b; Carvalho and Oliveira, 2009; Carvalho et al., 2007a; 2009a; 2009b; 2009c).

Radon $\left({ }^{222} \mathrm{Rn}, \mathrm{T}_{1 / 2}=3.8 \mathrm{~d}\right)$ is the immediate decay product of ${ }^{226} \mathrm{Ra}$ and it is a radioactive gas with a short half-life. Due to the long half-life of ${ }^{226} \mathrm{Ra}$, radon is continuously generated in the mill tailings and escapes to the atmosphere. Radon is a potent carcinogenic agent and exposure to this gas is now regulated WHO 2009. To prevent radon exhalation, the tailings can be covered with a multi-layer cap (compacted clay, gravel, textile geo membrane, or water layer), that allows for trapping or delaying the gas emanation from the tailings in order to allow for radon radioactive decay before escaping to the atmosphere.

Radioactive lead isotopes are present in the tailings and are continuously produced by ${ }^{226} \mathrm{Ra}$ decay. Particularly the long lived ${ }^{210} \mathrm{~Pb}$ isotope $\left(\mathrm{T}_{1 / 2}=22.3 \mathrm{y}\right)$, which may form water soluble compounds and complexes in acid and alkaline conditions, is of major radiological concern. Concentrations of ${ }^{210} \mathrm{~Pb}$ are moderate in leakages from high acidity young mill tailings, but may increase over time with increasing neutralization of the tailing materials.

Polonium $\left({ }^{210} \mathrm{Po} ; \mathrm{T}_{1 / 2}=138.4 \mathrm{~d}\right)$ is of the utmost concern due to the radiotoxicity of this pure alpha emitter to humans and with leakage from tailings. The intake of ${ }^{210} \mathrm{Po}$ through consuming contaminated water or food is a main concern in radiation protection due to high absorption efficiency of this radionuclide through the digestive tract (Hunt and Allington, 1993; Harrison et al., 2007).

Thorium isotopes give a major contribution to the external gamma radiation emitted by the tailings. In acid leaching from tailings, Th concentrations especially ${ }^{234} \mathrm{Th}\left(\mathrm{T}_{1 / 2}=24.1 \mathrm{~d}\right)$ and ${ }^{230} \mathrm{Th}\left(\mathrm{T}_{1 / 2}=75,380\right.$ y) may be high because $\mathrm{Th}$ dissolution occurs at $\mathrm{pH}<4$ and thus it may disperse in the environment. However, as thorium is highly insoluble in near neutral $\mathrm{pH}$ aqueous media, it usually re precipitates with ferric hydroxides within a short distance from tailings. 
Am. J. Environ. Sci., 7 (6): 547-553, 2011

Table 1: Activity concentrations ( $\mathrm{Bq} \mathrm{kg}{ }^{-1}$, dry weight) of the main alpha emitting radionuclides in mining and milling waste $(<63 \mathrm{~m}$ grain size $)$ near old uranium mines, Portugal. Analytical uncertainties are less than $10 \%$ of the values shown (based on Carvalho et al., 2007b)

\begin{tabular}{|c|c|c|c|c|c|c|c|}
\hline & ${ }^{238} \mathrm{U}$ & ${ }^{235} \mathrm{U}$ & ${ }^{234} \mathrm{U}$ & ${ }^{230} \mathrm{Th}$ & ${ }^{226} \mathrm{Ra}$ & ${ }^{210} \mathrm{Po}$ & ${ }^{232} \mathrm{Th}$ \\
\hline Mill tailings Urgeiriça mine & 2530 & 118 & 2880 & 10340 & 24720 & 20350 & 410 \\
\hline Low grade ore heaps Urgeiriça mine & 38320 & 1720 & 38250 & 30115 & 15570 & 30820 & 425 \\
\hline Mill Tailings Cunha-baixa mine & 2030 & 90 & 2280 & 3600 & 6700 & 4700 & 460 \\
\hline Mill tailings Bica mine & 10700 & 480 & 11400 & 30000 & 50000 & 29000 & 180 \\
\hline SOIL Mangualde region & 230 & 10 & 236 & 301 & 619 & 287 & 226 \\
\hline
\end{tabular}

Other stable metals, such as arsenic, may also be released from mill tailings in acid waters (Akcil and Koldas, 2006; Gravilescu et al., 2009).

In the ore milling step of uranium production, radiological hazard for workers may occur in the milling facilities where radon gas and air dust concentrations need to be monitored and controlled. Occupational radiation doses must be also controlled either by external radiation dosimetry or/and by bioassay for monitoring internal contamination. Waste disposal in mill tailings and process water releases may originate noticeable radioactive contamination of the environment and exposure of the public to ionizing radiation. Appropriate mitigation measures that must be undertaken may include capping of tailings, waste water treatment and radioactivity monitoring of the food chain (IAEA, 2002).

Environmental impact of uranium mining and milling tailings: Uncovered uranium mill tailings are a source of radioactive gas (radon), dust particles, surface runoff and leakages that may disperse radionuclides in the environment and originate radiation doses to populations living in the region (IAEA, 1999; OECD/NEA, 2002; IAEA, 2005b; 2010).

The increased radioactivity around former uranium and mill tailings was investigated in several countries. Reports indicated contamination of soils, uptake by plants, dispersal in surface water streams and groundwater and enhanced radon in surface air especially in areas with uncovered mill tailings and without measures to reduce radionuclide concentrations. For example, high radionuclide concentrations from tailings leakage were measured in receiving surface streams, although concentrations dropped to baseline values in relatively short distances (several kilometers) from discharge points. Enhanced radionuclide concentrations were measured also in soils and plants irrigated with contaminated waters and in groundwater near mining and milling sites (IAEA, 2002; Carvalho et al., 2011). Acid mine drainage is one long lasting and persistent impact that continuously requires treatment over long periods. This treatment may, however, incidentally contribute to introduce radionuclides in the vegetation (IAEA, 1999; Merkel and Hasche-Berger, 2008).

In several countries uranium tailing materials have thus caused contamination of soils, surface waters and groundwater. Furthermore, failure of unstable tailing dams originated dispersal of radioactive wastes and environmental contamination in many places. In some areas, the use of mill tailing materials in house construction brought radioactive materials also into close contact with members of the public and increased exposure to ionizing radiation (IAEA, 2000). Many mill tailings from past uranium mining in Europe remained uncovered for many years, until the need for the remediation of legacy mine and milling sites was recognized (OECD/NEA, 2002; Merkel and HascheBerger, 2006).

Exposure of the population to radiation doses in the vicinity of mill tailings was determined in several countries. Environmental remediation efforts substantially reduced radiation doses and public exposures are now under better control (IAEA, 2000; OECD/NEA, 2002).

Future uranium production. A new paradigm: New mines licensed in African countries, Canada and Australia indicate that uranium mining is increasing worldwide WISE 2002 EURATOM, 2010. Former small uranium producers may also restart operations, as for example Spain and Portugal. With environmental regulations in place and more stringent radiation protection laws setting the exposure limit at $1 \mathrm{mSv} \mathrm{y}^{-1}$ for health protection of members of the public, all aspects of mining operations and waste management should be regulated under new guidelines.

Past mining activities were largely implemented before knowledge on ionizing radiation effects was developed, identification of radon as lung cancer agent in miners was discovered and development of environment protection regulations was enforced (IAEA, 2000). Therefore, it is not surprising that in most old mine sites there has been a need for intervention and environmental remediation.

Modern uranium mines need to plan the operations using modern concepts currently implemented in other activities, such as the «life cycle approach». This would 
imply that the mine planning shall be made taking into account components, such as the costs of decommissioning the mine and mill facilities and costs of environmental rehabilitation and environmental monitoring. These costs should be accounted for and included in the pricing of the commodity. As a result, future expansion of uranium mining and milling may be required to assume responsibility of the environmental impacts.

Mine planning should involve stakeholder contribution. Stakeholder involvement would contribute values of society, such as preserving sacred land for indigenous nations and human health concerns on exposure risk to radiation. Currently, decision making is based on economic values. More opposition to mining developments may occur from stakeholders in populated regions to preserve traditional values and good soil quality. In contrast, less populated regions such as sand deserts (e.g., uranium mines in the Sahara desert, Niger) and frozen Arctic regions (e.g., in Canada) experience reduced stakeholder conflict but can attract a local community to the mine location, whereby increasing risk of exposure to radiation for the new settlement. In all cases mining operations need to obtain the so called «societal license» and the stakeholder involvement in the process is considered an essential part of it.

\section{CONCLUSION}

Uranium mining and milling activities have occurred for one century but the demand for production of more and cleaner electric power, combined with the available uranium resources will probably boost uranium production in the next decades. The amount of mine and mill tailings existing worldwide is large and most are hazardous material due to high activity concentrations of long lived radiotoxic nuclides (e.g., ${ }^{226} \mathrm{Ra},{ }^{210} \mathrm{~Pb},{ }^{210} \mathrm{Po}$ ) and associated toxic stable metals (e.g., As, V). Many of these legacy tailings are uncovered and are even unstable (e.g., Kazakhstan), with radioactive wastes that were poorly disposed of without impermeable liners and caps. In the tailings that were recently engineered and covered, there are uncertainties about the durability of caps and recuperation of leakages to prevent surface water and groundwater contamination with radionuclides and toxic stable metals. Future operations have identified the need for environmental radioactivity surveillance around remediated tailings, custody of these sites and maintenance of the integrity of barriers to prevent effects from erosion and natural catastrophes. The cost of legacy tailings capping and radiological surveillance are high and this recommends that before the start of new mining operations, adequate planning should be made for the closure of mines and mills and environmental rehabilitation of sites. This implies a life cycle approach to the planning of uranium mines, including waste management, environmental radioactivity monitoring and radiological risk assessment to the environment and to the local population.

\section{REFERENCES}

Akcil, A. and S. Koldas, 2006. Acid mine drainage (AMD): Causes, treatment and case studies. J. Cleaner Product., 14: 1139-1145. DOI: 10.1016/j.jclepro.2004.09.006

Borch, T., R. Kretzschmar, A. Kappler, P.V. Cappellen and M. Ginder-Vogel et al., 2010. Biogeochemical redox processes and their impact on contaminant dynamics. Environ. Sci. Technol., 44: 15-23. DOI: 10.1021/es9026248

Carvalho, F.P., J.M. Oliveira, I. Lopes and A. Batista, 2007a. Radionuclides from past uranium mining in rivers of Portugal. J. Environ. Radioactivity, 98: 298-314. DOI: 10.1016/j.jenvrad.2007.05.007

Carvalho, F.P., M.J. Madruga, M.C. Reis, J.G. Alves and J.M. Oliveira et al., 2007b. Radioactivity in the environment around past radium and uranium mining sites of Portugal. J. Environ. Radioactivity, 96: 39-46. DOI: 10.1016/j.jenvrad.2007.01.016,

Carvalho, F.P. and J.M. Oliveira, 2009. Performance of alpha spectrometry in the analysis of uranium isotopes in environmental and nuclear materials. J. Radioanal. Nucl. Chem., 281: 591-596. DOI: 10.1007/s10967-009-0046-2

Carvalho, F.P., J.M. Oliveira, M.O. Neves, M.M. Abreu and E.M. Vicente, 2009a. Soil to plant (Solanum tuberosum L.) radionuclide transfer in the vicinity of an old uranium mine. Geochemistry: Exploration, Environ. Anal., 9: 275-278.

Carvalho, F.P., J.M. Oliveira and M. Malta, 2009b. Analyses of radionuclides in soil, water and agriculture products near the Urgeiriça uranium mine in Portugal. J. Radional. Nucl. Chem., 281: 479-484. DOI: $10.1007 / \mathrm{s} 10967-009-0027-5$

Carvalho, F.P., J.M. Oliveira and I. Faria, 2009c. Alpha emitting radionuclides in drainage from quinta do bispo and cunha baixa uranium mines (Portugal) and associated radiotoxicological risk. Bull. Environ. Contaminat., Toxicol., 83: 668-673. DOI: 10.1007/s00128-009-9808-3

Carvalho, F.P., J.M. Oliveira and M. Malta, 2011. Radionuclides in plants growing on sludge and water from uranium mine water treatment. Ecol. Eng., 37: 1058-1063. DOI: 10.1016/j.ecoleng.2010.07.011 
Eisenbud, M. and T.F. Gesell, 1997. Environmental Radioactivity: From Natural, Industrial and Military Sources. 4th Edn., Academic Press, New York, ISBN: 0122351541, pp: 656.

ESA, 2009. Euratom Supply Agency: Annual Report 2008. 1st Edn., Office for Official Publications of the European Communities, Luxembourg, ISBN: 9279125613, pp: 41.

Gravilescu, M., L.V. Pavel and I. Cretescu, 2009. Characterization and remediation of soils contaminated with uranium. J. Hazard. Mater., 163: 475-510. DOI: 10.1016/j.jhazmat.2008.07.103

Hala, J. and J.D. Navratil, 2003. Radioactivity, Ionizing Radiation and Nuclear Energy. 1st Edn., Konvoj, Brno, Czech Republic, ISBN-10: 807302053X, pp: 467.

Harrison, J., R. Leggett, D. Lloyd, A. Phipps and B. Scott, 2007. Polonium-210 as a poison. J. Radiol. Prot., 27: 17-40. DOI: 10.1088/0952-4746/27/1/001

Hunt, G.J. and D.J. Allington, 1993. Absorption of environmental polonium-210 by the human gut. J. Radiol. Prot., 13: 119-26. DOI: 10.1088/09524746/13/2/003

IAEA, 1999. Environmental Activities in Uranium Mining and Milling. 1st Edn., OECD Publishing, Paris, ISBN: 9264170642, pp: 173.

IAEA, 2000. Restoration of Environments with Radioactive Residues. 1st Edn., International Atomic Energy Agency, Vienna, pp: 697.

IAEA, 2002. Monitoring and Surveillance of Residues from the Mining and Milling of Uranium and Thorium. 1st Edn., International Atomic Energy Agency, Vienna, pp: 65.

IAEA, 2005a. Long Term Stabilization of Uranium Mill Tailings. 1st Edn., International Atomic Energy Agency, Vienna, ISBN: 920108904X, pp: 311.
IAEA, 2005b. Environmental contamination from uranium production facilities and their remediation. 1st Edn., International Atomic Energy Agency, Vienna, ISBN: 9201043058, pp: 262.

IAEA, 2006. Nuclear Power Reactors in the World. 1st Edn., International Atomic Energy Agency, Vienna.

IAEA/OECD, 2010. Uranium 2009: Resources, Production and Demand. 1st Edn., OECD Publishing, Paris, ISBN: 9264047905, pp: 425.

ICRP, 1991. Recommendations of the International Commission on Radiological Protection. 1st Edn., Elsevier Health Sciences, Oxford, ISBN: 0080411444, pp: 201.

Malyshkina, N. and D. Niemeier, 2010. Future Sustainability forecasting by exchange markets: Basic theory and an application. Environ. Sci. Technol., 44: 9134-9142. DOI: 10.1021/es $100730 \mathrm{q}$

Martin, A.J., J. Crusius, J.J. McNee and E.K. Yanful, 2003. The mobility of radium-226 and trace metals in pre-oxidized subaqueous uranium mill tailings. Applied Geochem., 18: 1095-1110. 10.1016/S0883-2927(02)00243-3

Merkel, B. and A. Hasche-Berger, 2006. Uranium in the Environment: Mining Impact and Consequences. 1st Edn., Springer, Berlin, ISBN: 3540283633, pp: 897.

Merkel, B.J. and A. Hasche-Berger, 2008. Uranium, Mining and Hydrogeology. 1st Edn., Springer, Berlin, ISBN: 3540877452, pp: 955.

OECD/NEA, 2002. Environmental Remediation of Uranium Production Facilities. 1st Edn., OECD Publishing, Paris, ISBN: 9264194800, pp: 323. 